\title{
Examining the Relationship between Efficiency and Capital Adequacy Ratio: Islamic versus Conventional Banks --- An Empirical Evidence on Egyptian Banks
}

\author{
Hassan Mohamed Mohamed Hafez ${ }^{1}$ \\ ${ }^{1}$ Business Administration Department, Canadian International College (“CIC"), New Cairo, Egypt \\ Correspondence: Hassan Mohamed Mohamed Hafez, Business Administration Department, Canadian International \\ College (“CIC"), New Cairo, Cairo- Egypt.
}

Received: March 31, 2018

Accepted: April 27, 2018

Online Published: April 29, 2018

doi:10.5430/afr.v7n2p232

URL: https://doi.org/10.5430/afr.v7n2p232

\begin{abstract}
This paper aims to investigate the relationship between the efficiency of banks in Egypt and capital adequacy ratios. We collected data on a sample of 40 banks comprising Islamic banks, conventional and conventional banks with Islamic windows pre and post the global financial crisis from year 2002 to 2015 . We used data envelopment analysis liner programming (DEA) to calculate the efficiency of banks then we used a panel regression analysis through the application of Eviews software to investigate the relationship between the efficiency of banks and capital adequacy ratios. Pre the financial crisis, results, concluded that, there is a significant positive relationship between the efficiency of banks and capital adequacy ratios, credit risk, profitability, bank size and the quality of management. Whilst a significant negative relationship with the liquidity. The efficiency of conventional banks outperformed the efficiency of Islamic and conventional banks with Islamic windows. The increase in capital follows an increase in the level of risk borne by banks and increases capital adequacy ratios which leads to a rise in the loan portfolio and therefore, increase the level of loans provisions, which confirms the high level of efficiency for banks. Capital increase provide an additional protection against any additional risks. Post the financial crisis, the efficiency of banks has been affected especially for conventional banks. The efficiency of conventional and conventional banks with Islamic windows shows a negative significant relationship with capital adequacy ratios. The efficiency of Islamic banks outperformed other banks and shows a positive significant relationship with capital adequacy ratios. Results revealed that the efficiency of banks determines the level of capital and risk borne by banks.
\end{abstract}

Keywords: DEA, efficiency, capital adequacy ratio, Egyptian banks

\section{Introduction}

The latest global financial crisis has raised many questions regarding how to protect financial institutions from the risks of bankruptcy and financial failure. Whether the traditional financial system is the optimal system to achieve prosperity and increase the economic growth by increasing risk adjusted rates of return. On the other side. the Islamic financial system primarily focuses on risk sharing and distribution of profits to all involved parties. The financial crisis cast a shadow over financial and monetary policymakers of central banks to impose many financial restrictions to ensure the protection of financial institutions and protect the global financial system from collapse. The global financial depression in 1930s is not out of minds especially after the collapse of Lehman Brothers in September 2008. During the financial crisis banks exposed to high leverage and liquidity crunch along with poor risk management. Accordingly, these factors leads to a poor quality in the loans portfolio and higher exposure to liquidity risks. Therefore, the Basel Committee issued additional terms and conditions to strengthen the capital framework as follows:

- An additional portion of common equity to meet the minimum requirement of capital.

- A countercyclical capital buffer to impose a maximum limits on banks participation in providing credit for the sake to reduce the non-performing loans.

A minimum capital requirement were placed in from year 2013, and became effective at the beginning of year 2015. as follows: 
- A minimum capital requirements increased from $2 \%$ and $4 \%$ to $3.5 \%$ and $4.5 \%$, from year 2004 then increased to reach $4 \%$ and $5.5 \%$ respectively from year 2013. And then, the final requirements for common equity were set at $4.5 \%$ and $6 \%$, respectively, at the beginning of year 2015 .

- The $2.5 \%$ capital conservation buffer, and the $4.5 \%$ minimum requirement, will be phased gradually starting on 1 January 2016, and will become effective at the beginning of January 2019.

\subsection{Overview of the Banking Sector in Egypt}

There are currently forty banks operate in Egypt. The central bank of Egypt has not issued any new license to practice banking operation since 1979. In order to get a banking license this should be through purchasing an existing bank. Recently, there are many cases of regional banks who purchased an existing banks in Egypt for example: The case of Qatari National Bank Group when acquired National Société Générale Bank (NSGB) in 2013. In year 2016 the Egyptian government expressed its desire to partially privatize less than 50 percent two of state-owned banks through public offering in the Stock Exchange. By year-end 2016, Banks operate in Egypt held EGP 2.485 trillion in total assets, of which approximately $60 \%$ were held by the largest five banks in Egypt, namely: the National Bank of Egypt, Banque Misr, the Commercial International Bank, Qatar National Bank Al-Ahli, and the Banque Du Caire. Only $8 \%$ of the banking sector's loans are non-performing loans. Since year 2011, $40 \%$ of banking assets exposure in government debt has reduced the diversity of bank balance sheets and affected the domestic investment. $20 \%$ of bank corporate loans go to SMEs. 14\% of Egypt's population owning an account. The banking sector in Egypt has still a potential for further improvement, growth and higher inclusion. By increasing the number of banks operating in Egypt, competition is fierce and banks are working to increase their capital in order to achieve higher returns that are commensurate with the business risks in the Egyptian market. A positive relationship between capital and risk is therefore expected. In addition, the capital adequacy ratios reflect the capital base of Egyptian banks weighted by risky assets. The central bank of Egypt allows efficient banks with good management to use high leverage and exposed to high risk than inefficient banks. As a result of increased competition and for banks to achieve high profit, efficient banks are expected to accept high risk. In light of this assumption, it is expected that there is a strong correlation between capital adequacy ratio and the efficiency of banks operating in Egypt. This research aims to study the relationship between capital adequacy ratios and banks efficiency in Egypt. Moreover, the extent to which such a relationship is established. through dividing banks into conventional commercial banks, conventional commercial banks with Islamic windows and Islamic commercial banks. What is the direction and strength of this relationship of each category of banks. Current research on Islamic finance in Egypt did not take into account the interrelationship between capital adequacy ratios and banks efficiency. Therefore, this research is a pioneer study presents a new fact about Egyptian banks. It also helps policy makers to formulate polices in order to strengthen the banking sector in Egypt.

\subsection{The Importance of Research}

Banks as a financial intermediary assist in the movement of money from lenders to borrowers. Banks contribute effectively to the mobility of capital within the economy. Its main objective is to make all participants better off. Banking is a very sensitive activity because the increase in the loans portfolio is the result of the increase in depositors' funds. The central Bank of Egypt as the main regulator of Egyptian banks plays an important role to ensure that all banks operate in Egypt maintain the minimum requirement of capital as defined by the Basel Committee. The central bank of Egypt encourages banks to increase capital adjusted to the market risk to compete efficiently in the market through the increase in market share and maximize profit. Therefore, Investigating the capital adequacy ratios of Egyptian banks is a necessity to ensure the financial stability of banks against the risk of bankruptcy. The exposure of any bank in Egypt to the risk of bankruptcy or financial failure gives a negative signal to investors and a warning message about how the economy suffers. The efficiency of Egyptian banks affects both the operating efficiency and market share of banks. Therefore, it has a direct impact on estimated profit. The Central Bank of Egypt is regularly considering the efficiency of banks when reviewing the financial standards and requirements imposed by the Basel Committee to ensure the well-functioning of banks in Egypt.

\subsection{Research Originality}

Taking into account the global financial crisis that occurred in 2007 and 2008. The high attention of monetary and fiscal policy makers of central banks around the world in setting the necessary standards to ensure the stability of the global financial system. Especially banks as a main pillar of the financial system. It is logical to regularly examine the relationship between the efficiency of banks and capital adequacy ratios. This is a novel research to further study such interrelationship since Egypt adopts the dual banking system. Moreover, the absolute absence of any research examined this interrelationship before. This research paper will be an added value in the field of banking by 
producing a new fact on banking sector in Egypt since all previous studies examined the relationship between efficiency of banks, capital and risk and without considering the capital adequacy ratio.

\subsection{Literature Review}

There are no studies on the relationship between banks' efficiency and capital adequacy ratios. Studies on the relationship between banks' efficiency and capital and risk are scarce. Early studies reviewed the basic characteristics of Islamic banks that derive from Islamic finance compared to conventional banks. Early studies basically have dealt with the differences between Islamic banks and conventional banks, as well as the development and success of Islamic banks over the past ten years. The rapid development and success of Islamic banks and their ability to compete with conventional banks has attracted the attention of many researchers. Recent researchers compared Islamic commercial banks against conventional commercial banks from a number of axes: profits, risks and efficiency. For example, Iqbal (2001), find that Islamic commercial banks outperformed conventional commercial banks. Brown et al. (2007) proved that the higher increase in capital and higher cost efficiency in Islamic banks compared to conventional banks especially if we talk about those countries that adopt the dual banking system. Most Islamic banks are relatively new compared to conventional banks and therefore, cannot exploit economies of scale and compete with conventional banks. Thus, the superiority of Islamic banks over conventional banks has proved if Islamic banks charge their customers the same rates as for conventional banks. Furthermore, other studies have demonstrated the Islamic banks to compete in parallel with conventional banks, Serder et al. (2011), and Mokhtar et al. (2006) study which proved Islamic banks superior to conventional banks in Malaysia from a competency perspective. Some other studies have focused on the relationship between efficiency, capital and risk. Banks with low efficiency have greater appetite to take higher risks in order to increase profits. Banks with low capital bear a higher risk. Altunbas et al, ( 2007) examined the relationship between efficiency, capital, risk and moral hazard. The capital and efficiency of banks are key determinants of bank's risk tolerance and moral hazard. Capital is expensive resource, banks with higher capital increase the level of risk in order to maximize returns accordingly those Banks enjoy high efficiency.

There are many in many studies examined the relationship between capital, risk and the efficiency of banks in many countries. Altunbas et al. (2007), investigated number of 15 European countries during the period from year 1992 to 2000, results revealed that inefficient banks bear a low risk as their capital increase. However, Fiordelisi et al (2010), analyzed data from EU countries during the period from year 1995 to 2007, the higher the bank's capital, the lower the cost compared to low capital banks. Banks with high efficiency also raise their capital with a positive relationship with their efficiency levels. They also reported a positive correlation between risk and low efficiency. Hughes and Mester (1998), find that the efficiency of banks determines the level of risk and capital. Mosko, Aida; Bozdo, Anilda (2015), investigated the relationship between efficiency, capital and risk-taking behaviour of banks operating in Albania during the period from year 2002 to 2014. Results revealed that a positive tradeoff between inefficiency and bank risk-taking (American banks evidence) and a negative one (European banks evidence) that seem to hold more capital and take on less risk in case of inefficiency. Other previous studies have shown contradictory results. Berger, De Young, Kwan and Eisenbeis ((1997) affirmed that bank's risk is determined by the efficiency of bank and capital. The higher in capital capital ratios, the high increase in risk and this does not affect the likelihood of financial failure. In Contrast, Dahl and Shrives(1992) find that there is a negative relationship between capital and risk. Risk occurs when depositors are insured with a flat premium. As a result we can assume that adequate capital requirement could reduce higher risk. Hellmann et al. (2000), argued that the higher capital requirement might give an incentive to banks to bear more risk. Simon and Robert (1997), examine further the interrelationship between interest rate, credit risk, capitalization and operating efficiency of American banks. Results revealed that there is a positive effect of banks inefficiency on risk taking which is support the moral hazard hypothesis that poor performance banks are more effected to risk taking rather than high performance banks.

There is also a positive effect between efficiency and capital. Miah and Sharmeen (2015), investigated the relationship between capital, risk and efficiency on a sample of banks operate in Bangladesh from year 2001 to 2011. Results concluded that conventional commercial banks are more efficient in cost management. The direction of relation between capital and risk of Islamic banks is bidirectional and positive. However, it is negative for conventional banks. The above mixed results reveals that there is a direct casual relationship between, risk, capital and the efficiency of banks. These results attributed to the fact that the three factors could be depend on other factors such as: moral hazard, asymmetric information, ownership structure and agency problem.

\subsection{Research Hypothesis}

According to the literature review and the purpose of this study we can state the null hypothesis as follows: 


\subsection{1 the Null Hypothesis}

$\mathrm{H}_{\mathrm{o}}$ : the relationship between the efficiency of banks in Egypt and capital adequacy ratios is negative or zero.

1.5.2 against the Alternative Hypothesis

$\mathrm{H}_{1}$ : the relationship between efficiency of banks in Egypt and capital adequacy ratios is positive.

There is a significant positive relationship between the efficiency of banks and capital adequacy ratios.

$\mathrm{H}_{2}$ : there is no statistical significant difference between the three main categories of banks; Islamic banks, conventional and conventional banks with Islamic windows - when investigating the relationship between bank's efficiency and capital adequacy ratio - during the study period pre and post the global financial crisis.

\section{Data and Methodology}

\subsection{Sample Selection}

40 commercial banks operate in Egypt were used for observation in this study and excluded investment banks due to the use of inputs and outputs of commercial banks. Thus the total sample was 560 (40 banks with 14 annual observations). We examined the impact of the efficiency of banks on capital adequacy ratios pre the financial crisis from year 2002 to 2008 and post the financial crisis from year 2008 to 2015. The study sample has been divided into three main categories; 5 Islamic commercial banks, 5 conventional commercial banks with Islamic windows and 35 conventional commercial banks. Number of observations is enough to obtain a reliable results. Bank scope data base is used to obtain banks' balance sheets and income statements. We used also quarterly financial statements published on the website of each bank. The data is yearly data from year 2002 to 2015 in millions of Egyptian pounds.

\subsection{Banks Outputs and Inputs}

Drake at al. (2006) and Frexias and Rochat (1997) and other researchers stated that there are two main approaches utilized in the banking literature to define inputs and outputs for banks. The first approach is proposed by Benston (1965) called the production approach, and the intermediation approach proposed by Sealey and Lindley (1977). According to the first approach - production approach- we consider financial institutions as providing services to customers. The inputs according to this approach include variables such as labor and material. And the outputs are the financial services provided to clients. Many previous studies used this approach to investigate the efficiency of bank branches.

The second approach is called the intermediation approach or asset approach. In this approach we consider banks as financial intermediaries their main function is to collect deposits from clients and provides loans to borrowers or invest funds in the local and international markets. According to this approach inputs variables include deposits and fixed assets among other variables and output variables include loans and net income. Following Ariss et al (2007), Bader et al. (2008), Benjelloum and Zeitun(2013), Grigorian and Manole (2005) and Limam (2001) this study applied the intermediation approach in defining output and input variables. Berger and Humphrey (1997) stated that the intermediation approach is recommended because it reflects the production function of banks. Total deposits and assets represent the input variables and total loans and net income represent the output variables. Table 2 shows a summary of the output and input variables used in this study before the pre financial crisis. Whilst, table 4. Shows the output and input variables applied in this study post the financial crisis.

\subsection{Model Specification to Measure the Efficiency of Banks}

We used the updated data development analysis using the concept of linear programming to construct a non-parametric piecewise frontier over the sample data in order to compute the efficiency of Egyptian banks. The production function of the fully efficient bank is not known, therefore the efficiency of Egyptian banks must be estimated through using observations on a sample consist of currently 40 banks operate in Egypt. The DEA model updated to CCR model as per input orientation. This model is highly recommended because it is possible to make comparison between large and small banks specially if the frequency distribution is skewed.

The economic efficiency of any bank consist of two components; technical efficiency which reflect the ability of a bank to maximal output from a given set of inputs and allocative efficiency which reflects the ability of a bank to use an inputs in optimal proportions (Fare \& Gross Kopf and Lovell 1994). Those two measures are combined together to provide a measure of total efficiency. The technical efficiency can be expressed and commonly measured by $\mathrm{TE}_{1}=0 \mathrm{Q} / 0 \mathrm{P}$ which is equal $1-(\mathrm{QP} / 0 \mathrm{P})$. It will always take a value range from zero to 1 . If the bank is got 1 this means that the bank is fully efficient. Moreover, we can calculate the allocative efficiency of a bank operating as 
$\mathrm{AE}_{1}=0 \mathrm{R} / 0 \mathrm{Q}$. We used the CSR model based on input orientation concept to allow us to compare between large, medium and small banks. Total economic efficiency of any banks EE1 $=0 \mathrm{R} \times 0 \mathrm{P}$.

By the application to each bank we obtain a measure of the ratio of all outputs over all inputs such as (o $y_{i} / n^{\prime} x_{i}$ ) where $u$ is an $M \times 1$ vector of outputs weights and $v$ is an $K \times 1$ vector of input weight. The technical efficiency of banks in Egypt will be calculated by taking the highest value of the weighted outputs into the weighted inputs. In that way multiple input and output of banks to be reduced to one input and output by obtaining the optimal weighting.

$$
\text { Maxu,v (o'yi / n'xi) }
$$

Subject to:

$$
\begin{gathered}
\text { o'yi / n'xi } \leq 1, \mathrm{j}=1,2, \ldots, \mathrm{n} \\
\mathrm{o}, \mathrm{n} \geq 0,
\end{gathered}
$$

This includes finding the values of $\mathrm{o}$ and $\mathrm{n}$ in order to calculate the maximized values of the efficiency of Egyptian banks. We consider the main constraint that the value of Egyptian banks efficiency $\leq 1$ as a result we can get an infinite number of solutions. To overcome this statistical issue we put a constant constraints, that $n$ 'xi $=1$ and obtained the following formula:

$$
\operatorname{Max} \mu, v \text { (o’yi), }
$$

Subject to:

$$
\begin{aligned}
& \text { p'xi }=1, \\
& \mu^{\prime} y i-p \text { 'xi } \leq 1, \quad \text { j=1,2, } \quad ., n \\
& \mu, p \geq 0,
\end{aligned}
$$

The notation change from $\mathrm{u}$ and $\mathrm{v}$ to $\mu$ and $\mathrm{p}$ reflecting the transformation. This form is the multiplier from the linear programming problem. We obtain and equivalent envelopment of the linear programming problem as follows:

$$
\begin{gathered}
\operatorname{Min} \theta, \lambda \quad \theta, \\
-y i+\mathrm{Y} \lambda \geq 0, \\
\theta x i \quad-\mathrm{X} \lambda \geq 0, \\
\lambda \geq 0
\end{gathered}
$$

where $\theta$ is a scalar and $\lambda$ is an NX1 vector of constant. The value of $\theta$ is the value of efficiency for Egyptian banks. It has to be solved $\mathrm{N}$ times according to the number of Egyptian banks included in the study sample.

It is important to mention that we meet the minimum requirement to conduct the DEA analysis as per the rule $\mathrm{n} \geq$ $\max \{\mathrm{m} \times \mathrm{s}, 3(\mathrm{~m}+\mathrm{s})\}$. We can say that ( 2 inputs $\times 2$ outputs, $3(2+2)$ ). Therefore, we conclude that the number of variables used in this study are reliable to conduct an efficient analysis.

\subsection{Relationship between Efficiency and Capital Adequacy Ratio}

There is a lack of studies on the relationship between the efficiency of banks, capital and risk in developed countries especially Egypt. In this study, we introduce a new approach to investigate the relationship between the capital adequacy ratio taking into account the risky assets, reflecting the degree of risk of these assets and the efficiency of banks operating in Egypt prior and post the global financial crisis. A system of equations has been estimated to allow for a study of the interrelationship between the efficiency of banks and capital adequacy ratios. At the same time with the focus of other bank specific factors.

The Efficiency of banks $_{i t}=\alpha+\beta_{1}\left(\right.$ CAR $\left._{i t}\right)+\beta_{2}$ (Loans/Assets $\left.i t\right)+\beta_{3}$ (Provisions/Loans $\left.i t\right)+\beta_{4}$ (Loans/Deposits $\left.i, \mathrm{t}\right)$ $+\beta_{5}\left(\operatorname{ROA}_{i t}\right)+\beta_{6}(\log$. Assets $i t)+\varepsilon_{i} \quad i=1, \ldots 8 \quad t=1, . .9$

Capital adequacy ratio ${ }_{i t}=\alpha+\beta_{1}$ (the efficiency of Banks ${ }_{i t}$ ) $+\beta_{2}$ (Loans/Assets $\left.{ }_{i t}\right)+\beta_{3}$ (Provisions/Loans $\left.{ }_{i t}\right)+\beta_{4}$ $($ Loans/Deposits $i, \mathrm{t})+\beta_{5}\left(\mathrm{ROA}_{i t}\right)+\beta_{6}\left(\log\right.$. Assets $\left.{ }_{i t}\right)+\varepsilon_{i} \quad i=1, \ldots 8 \quad t=1, . .9$

$\alpha$ is a constant, $\left(\beta_{1}: \beta_{6}\right)$ are the parameters for the explanatory variables. The subscript (i) refers to the bank number and the subscript $(t)$ denotes the time period. $\left(\varepsilon_{i}\right)$ is the unobservable individual heterogeneity, and $v_{i t}$ is the remainder disturbance of the usual disturbance in the regression model that varies with individual units and time. The independent and dependent variables of the study are defined and measured as follows (Hafez, H. M El-Ansary, O., 2015). 
Table 1. dependent and independent variables

\begin{tabular}{|c|c|}
\hline \multicolumn{2}{|r|}{ Dependent Variable } \\
\hline The Efficiency Index & Through the application of (DEA) \\
\hline \multicolumn{2}{|r|}{ Independent variables } \\
\hline \multirow{3}{*}{ Capital Adequacy Ratio } & Sublmintary Capital + Primary Capital \\
\hline & Risky Assets \\
\hline & (Tier 1 Capital + Tier 2 Capital) / Risky weighted assets \\
\hline \multirow{2}{*}{ Liquidity } & Net Client Loans \\
\hline & $\overline{\text { CShort term funds \& Clients deposits }} \times 100$ \\
\hline \multirow[b]{2}{*}{ Credit Risk } & Provisions of loans \\
\hline & $\overline{\text { Average Total Loans }} \times 100$ \\
\hline \multirow{2}{*}{ Profitability } & Net Profit after Tax \\
\hline & $\overline{\text { Average Total Assets }} \times 100$ \\
\hline Size & Log average total assets \\
\hline \multirow{2}{*}{$\begin{array}{l}\text { The Quality of } \\
\text { Management }\end{array}$} & Average Total Loans \\
\hline & $\overline{\text { Average Total Assets }} \times 1$ \\
\hline
\end{tabular}

Table 2. summary statistics of variables pre the financial crisis

\begin{tabular}{|c|c|c|c|c|c|}
\hline Year & Outputs & Mean & Minimum & Maximum & Standard deviation \\
\hline \multirow{2}{*}{2002} & Total Loans & 7,883 & 1,984 & 48,345 & 13,921 \\
\hline & Net Income & 411 & 73 & 1,989 & 612 \\
\hline \multirow[b]{2}{*}{2003} & Total Loans & 8,135 & 2,034 & 52,873 & 14,317 \\
\hline & Nat Income & 442 & 82 & 2,217 & 646 \\
\hline \multirow{2}{*}{2004} & Total Loans & 8,464 & 2,117 & 59,242 & 15,762 \\
\hline & Net Income & 414 & 87 & 2,479 & 673 \\
\hline \multirow{2}{*}{2005} & Total Loans & 8,810 & 2,300 & 70,450 & 19,825 \\
\hline & Net Income & 404 & 116 & 2,717 & 652 \\
\hline \multirow{2}{*}{2006} & Total Loans & 9,258 & 2,317 & 76,049 & 21,233 \\
\hline & Net Income & 540 & 120 & 2,650 & 712 \\
\hline \multirow{2}{*}{2007} & Total Loans & 9,793 & 2,448 & 88,120 & 23,512 \\
\hline & Net Income & 579 & 150 & 2,983 & 751 \\
\hline \multirow{2}{*}{2008} & Total Loans & 10,622 & 2,655 & 116,719 & 24,753 \\
\hline & Net Income & 746 & 134 & 3,341 & 1,082 \\
\hline \multirow{3}{*}{2002} & Inputs & & & & \\
\hline & Total Deposits & 9,859 & 2,001 & 56,782 & 16,895 \\
\hline & Total Assets & 13,820 & 2,981 & 78,340 & 26,412 \\
\hline \multirow{2}{*}{2003} & Total Deposits & 10,520 & 2,339 & 69,110 & 19,752 \\
\hline & Total Assets & 16,513 & 2,814 & 99,708 & 28,730 \\
\hline \multirow{2}{*}{2004} & Total Deposits & 12,192 & 2,579 & 92,338 & 22,452 \\
\hline & Total Assets & 17,099 & 3,416 & 108,589 & 32,766 \\
\hline \multirow{2}{*}{2005} & Total Deposits & 13,848 & 2,822 & 103,930 & 25,413 \\
\hline & Total Assets & 18,149 & 3,451 & 120,883 & 38,565 \\
\hline \multirow{2}{*}{2006} & Total Deposits & 14,254 & 2,942 & 117,042 & 32,457 \\
\hline & Total Assets & 20,760 & 3,616 & 130,556 & 42,454 \\
\hline \multirow{2}{*}{2007} & Total Deposits & 16,572 & 3,069 & 148,561 & 41,782 \\
\hline & Total Assets & 23,799 & 3,892 & 174,188 & 51,802 \\
\hline \multirow{2}{*}{2008} & Total Deposits & 17,349 & 3,397 & 195,142 & 47,652 \\
\hline & Total Assets & 25,953 & 4,851 & 216,665 & 66,790 \\
\hline
\end{tabular}


Table 2. indicates the use of a number of criteria to assess the efficiency of banks in Egypt. The two most important variables were used according to the intermediation or asset approach as a main inputs to any bank: total deposits and total assets. As the employment of deposits and assets of the bank is the basis to increase the bank's market share and the composition of the loans portfolio to maximize profits. We find that the two common variables of the output components of any bank are loans and net income. DEA is used as a standard method to evaluate the efficiency and compare economic units during the same study (Coughlan et al., 2010). Using this method it is possible to identify more efficient banks through the use of output and input variables and to obtain the frontier of production.

Before the period of financial crisis and by analyzing bank's input variables, total deposits increased by $75 \%$ with an annual increase rate of $10.8 \%$. Total assets increased by $87.7 \%$ with an annual increase rate of $12.5 \%$. in terms of bank's output variables, total loans increased by $34.7 \%$ with an annual increase rate of $5 \%$. Net income increased by $81 \%$ with an annual increase rate of $11.7 \%$. We can attribute the increase in total assets and deposits due to the increase in number of branches of regional banks in the Gulf region and the Middle East due to their expansion policy.

Table 3. the efficiency of banks pre the financial crisis

\begin{tabular}{|c|c|c|c|c|c|}
\hline Year & The efficiency index & $\begin{array}{c}\text { All } \\
\text { Banks }\end{array}$ & $\begin{array}{c}\text { conventiona } \\
\text { I } \\
\text { banks }\end{array}$ & $\begin{array}{c}\text { Islamic } \\
\text { windows }\end{array}$ & $\begin{array}{c}\text { Islamic } \\
\text { banks }\end{array}$ \\
\hline \multirow{3}{*}{2002} & Efficiency: & 0.871 & 0.862 & 0.835 & 0.841 \\
\hline & P. Technical efficiency & 0.922 & 0.920 & 0.910 & 0.912 \\
\hline & S. Technical efficiency & 0.945 & 0.937 & 0.917 & 0.923 \\
\hline \multirow{3}{*}{2003} & Efficiency: & 0.910 & 0.882 & 0.825 & 0.854 \\
\hline & P. Technical efficiency & 0.949 & 0.939 & 0.902 & 0.937 \\
\hline & S. Technical efficiency & 0.959 & 0.940 & 0.915 & 0.912 \\
\hline \multirow{3}{*}{2004} & Efficiency: & 0.896 & 0.879 & 0.825 & 0.813 \\
\hline & P. Technical efficiency & 0.917 & 0.911 & 0.901 & 0.910 \\
\hline & S. Technical efficiency & 0.978 & 0.965 & 0.915 & 0.894 \\
\hline \multirow{3}{*}{2005} & Efficiency: & 0.929 & 0.892 & 0.820 & 0.895 \\
\hline & P. Technical efficiency & 0.942 & 0.923 & 0.899 & 0.939 \\
\hline & S. Technical efficiency & 0.987 & 0.967 & 0.913 & 0.954 \\
\hline \multirow{3}{*}{2006} & Efficiency: & 0.940 & 0.907 & 0.859 & 0.874 \\
\hline & P. Technical efficiency & 0.957 & 0.935 & 0.910 & 0.917 \\
\hline & S. Technical efficiency & 0.983 & 0.970 & 0.945 & 0.954 \\
\hline \multirow{3}{*}{2007} & Efficiency: & 0.908 & 0.852 & 0.824 & 0.878 \\
\hline & P. Technical efficiency & 0.9936 & 0.945 & 0.923 & 0.954 \\
\hline & S. Technical efficiency & 0.971 & 0.902 & 0.893 & 0.921 \\
\hline \multirow{3}{*}{2008} & Efficiency: & 0.909 & 0.862 & 0.836 & 0.893 \\
\hline & P. Technical efficiency & 0.898 & 0.956 & 0.932 & 0.960 \\
\hline & S. Technical efficiency & 0.970 & 0.901 & 0.897 & 0.931 \\
\hline
\end{tabular}

Table 3. indicates the efficiency of Egyptian banks before the global financial crisis divided by the three categories of banks. Results revealed that the efficiency of conventional banks outperformed the efficiency of conventional banks with Islamic windows and Islamic banks. Despite the fact that Egypt is one of the countries that adopt a dual bank system. However, conventional banks are the one with the largest market share. As the number of branches of conventional banks increases to cover all regions within Egypt. conventional banks followed by conventional banks with Islamic windows have established Islamic windows to offer Islamic products and services according to sharia 'a compliant to meet different segment of customers. In order for conventional banks with Islamic windows to meet all segments of depositors in Egypt, they bear high risks through increasing the loan portfolio to cover all economic 
sectors. This cannot happen without capital increase and efficiency in operations. Therefore, there is a significant relationship between the efficiency of banks and capital adequacy ratios to reflect risky assets according to Basel committee requirements. Islamic banks are ranked last in accordance with the efficiency index. The market share of Islamic banks in Egypt is still low compared to other banks, which means that Islamic banks have an area to increase market share in the future. The overall efficiency of Egyptian banks increased starting from year 2002 to year 2006 before decreasing again in year 2007 and 2008. It is clear from the table that scale efficiency is much better than pure efficiency meaning that Egyptian banks are not efficient enough in using their input resources.

Table 4. summary statistics of variables post the financial crisis

\begin{tabular}{|c|c|c|c|c|c|}
\hline Year & Outputs & Mean & Minimum & Maximum & Standard deviation \\
\hline \multirow{3}{*}{2009} & Total Loans & 10,937 & 2,434 & 55,872 & 16,317 \\
\hline & Net Income & 784 & 102 & 3,216 & 716 \\
\hline & Total Loans & 11,161 & 3,118 & 63,243 & 17,862 \\
\hline 2010 & Net Income & 812 & 131 & 3,779 & 817 \\
\hline \multirow{2}{*}{2011} & Total Loans & 11,250 & 3,903 & 77,459 & 21,626 \\
\hline & Income & 851 & 146 & 4,116 & 912 \\
\hline \multirow{2}{*}{2012} & Total Loans & 11,460 & 4,814 & 81,248 & 24,732 \\
\hline & Net Income & 885 & 190 & 4,953 & 1,235 \\
\hline \multirow{2}{*}{2013} & Total Loans & 11,752 & 5,848 & 93,130 & 26,212 \\
\hline & Net Income & 912 & 216 & 6,182 & 1,342 \\
\hline \multirow{2}{*}{2014} & Total Loans & 12,922 & 7,656 & 125,719 & 28,453 \\
\hline & Net Income & 956 & 312 & 6,942 & 1,451 \\
\hline \multirow{2}{*}{2015} & Total Loans & 14,120 & 8,823 & 145,830 & 31,562 \\
\hline & Income & 995 & 350 & 8,450 & 1,873 \\
\hline \multirow{3}{*}{2009} & Inputs & & & & \\
\hline & Total Deposits & 17,819 & 3,432 & 70,102 & 21,852 \\
\hline & Total Assets & 26,111 & 4,915 & 101,009 & 30,233 \\
\hline \multirow{2}{*}{2010} & Total Deposits & 17,992 & 4,879 & 94,238 & 23,751 \\
\hline & Total Assets & 26,997 & 6,116 & 110,509 & 35,866 \\
\hline \multirow{2}{*}{2011} & Total Deposits & 18,148 & 5,822 & 105,901 & 28,711 \\
\hline & Total Assets & 27,250 & 7,352 & 125,881 & 41,805 \\
\hline \multirow{2}{*}{2012} & Total Deposits & 18,453 & 6,741 & 117,342 & 35,552 \\
\hline & Total Assets & 27,860 & 7,816 & 135,525 & 47,651 \\
\hline \multirow{2}{*}{2013} & Total Deposits & 19,579 & 8,269 & 158,501 & 46,701 \\
\hline & Total Assets & 28,797 & 10,801 & 184,188 & 55,402 \\
\hline \multirow{2}{*}{2014} & Total Deposits & 21,545 & 10,307 & 199,102 & 51,652 \\
\hline & Total Assets & 29,650 & 13,952 & 220,695 & 70,904 \\
\hline \multirow{2}{*}{2015} & Total Deposits & 22,781 & 13,872 & 212,082 & 58,762 \\
\hline & Total Assets & 31,789 & 15,024 & 265,901 & 80,409 \\
\hline
\end{tabular}

After the financial crisis, results of the banking business were affected, results of the banking business were also affected by the revolution in 2011 . by analyzing bank's input variables, total deposits increased by $27.8 \%$ compared to $79 \%$ before the financial crisis with an annual increase rate of $3.9 \%$. Total assets increased by $21.7 \%$ compared by $87.7 \%$ before the financial crisis with an annual increase rate of 3.1\%. in terms of bank's output variables, total loans increased by $29.1 \%$ compared to $34.7 \%$ before the financial crisis with an annual increase rate of $4.1 \%$. Net income increased by $26.9 \%$ compared to $81 \%$ before the financial crisis with an annual increase rate of $3.8 \%$. 
It is noteworthy that post the financial crisis, the efficiency of the Egyptian banks has been decreased because a number of Egyptian banks have branches in foreign countries. In addition, the investments portfolio of Egyptian banks includes securities and bonds traded in international markets. Table 5. Indicate that the efficiency of Islamic banks outperformed both the efficiency of conventional banks with Islamic windows and the efficiency of conventional banks respectively. It is clear that scale efficiency outperformed pure efficiency in the case of conventional banks and conventional banks with Islamic windows. However, in the case of Islamic banks the pure efficiency outperformed the scale efficiency. This means that the management of Islamic banks are more efficient in using different resources of the bank. These results could be attributed to the fact that Islamic banks in Egypt are branches and extensions of head offices for Islamic banks in the Gulf region and the Middle East. This affects the scope of operations of Islamic banks in Egypt. Islamic banks in the region has a successful track record of banking operations and expertise with competence and high technical skills.

Table 5. the efficiency of banks post the financial crisis

\begin{tabular}{|c|c|c|c|c|c|}
\hline Year & The efficiency index & $\begin{array}{c}\text { All } \\
\text { Banks }\end{array}$ & $\begin{array}{c}\text { conventiona } \\
\text { I } \\
\text { banks }\end{array}$ & $\begin{array}{c}\text { Islamic } \\
\text { windows }\end{array}$ & $\begin{array}{c}\text { Islamic } \\
\text { banks }\end{array}$ \\
\hline \multirow{3}{*}{2009} & Efficiency: & 0.716 & 0.693 & 0.781 & 0.777 \\
\hline & P. Technical efficiency & 0.884 & 0.869 & 0.879 & 0.890 \\
\hline & S. Technical efficiency & 0.811 & 0.798 & 0.889 & 0.874 \\
\hline \multirow{3}{*}{2010} & Efficiency: & 0.601 & 0.592 & 0.685 & 0.726 \\
\hline & P. Technical efficiency & 0.785 & 0.764 & 0.778 & 0.885 \\
\hline & S. Technical efficiency & 0.764 & 0.775 & 0.881 & 0.821 \\
\hline \multirow{3}{*}{2011} & Efficiency: & 0.720 & 0.691 & 0.704 & 0.724 \\
\hline & P. Technical efficiency & 0.834 & 0.821 & 0.830 & 0.860 \\
\hline & S. Technical efficiency & 0.864 & 0.842 & 0.849 & 0.842 \\
\hline \multirow{3}{*}{2012} & Efficiency: & 0.790 & 0.718 & 0.741 & 0.740 \\
\hline & P. Technical efficiency & 0.892 & 0.825 & 0.840 & 0.886 \\
\hline & S. Technical efficiency & 0.886 & 0.871 & 0.883 & 0.836 \\
\hline \multirow{3}{*}{2013} & Efficiency: & 0.765 & 0.734 & 0.749 & 0.740 \\
\hline & P. Technical efficiency & 0.870 & 0.852 & 0.861 & 0.879 \\
\hline & S. Technical efficiency & 0.880 & 0.862 & 0.871 & 0.843 \\
\hline \multirow{3}{*}{2014} & Efficiency: & 0.790 & 0.769 & 0.784 & 0.781 \\
\hline & P. Technical efficiency & 0.883 & 0.873 & 0.882 & 0.895 \\
\hline & S. Technical efficiency & 0.895 & 0.882 & 0.890 & 0.873 \\
\hline \multirow{3}{*}{2015} & Efficiency: & 0.797 & 0.769 & 0.793 & 0.798 \\
\hline & P. Technical efficiency & 0.887 & 0.872 & 0.881 & 0.904 \\
\hline & S. Technical efficiency & 0.899 & 0.882 & 0.901 & 0.883 \\
\hline
\end{tabular}

\section{Capital adequacy ratio and banks efficiency}

Efficiency $_{i t}=\alpha+\beta_{1}$ (capital adequacy ratio $\left._{i t}\right)+\beta_{2}$ (Loans/Assets $\left._{i t}\right)+\beta_{3}$ (Provisions/Loans $\left.{ }_{i t}\right)+\beta_{4}$ (Loans/Deposits $i$, t) $+\beta_{5}\left(\right.$ ROA $\left._{i t}\right)+\beta_{6}(\log$. Assets $i t)+\varepsilon_{i} \quad i=1, \ldots 8 \quad t=1, . .9$

$\operatorname{CAR}_{i t}=\alpha+\beta_{1}$ (Bank Efficiency $\left._{i t}\right)+\beta_{2}$ (Loans/Assets $\left.{ }_{i t}\right)+\beta_{3}$ (Provisions/Loans $\left.{ }_{i t}\right)+\beta_{4}$ (Loans/Deposits $\left.i, \mathrm{t}\right)+\beta_{5}$ $\left(\mathrm{ROA}_{i t}\right)+\beta_{6}\left(\log\right.$. Assets $\left.{ }_{i t}\right)+\varepsilon_{i} \quad i=1, \ldots 8 \quad t=1, . .9$ 
Table 6. descriptive statistics

\begin{tabular}{lcccccccc}
\hline & Min. & Max. & Mean & Median & Skewness & kurtosis & SD & Jarque-Bera \\
\hline \multicolumn{7}{c}{ Dependent Variable } \\
\hline The Efficiency of Banks & .0020 & .4061 & .14312 & 0.1123 & 1.1401 & 2.927 & .1014 & 211,201 \\
\hline \multicolumn{7}{c}{ Independent Variables } \\
\hline Capital Adequacy Ratio & .0041 & 1.0106 & .3291 & 0.3412 & $-1.423-$ & 26.278 & .1062 & 12343.03 \\
\hline Loans/ Avg. Assets & .0102 & 1.1310 & .3267 & 0.5441 & 3.291 & 1.431 & .2130 & 83.7314 \\
\hline Provisions/Avg. Loans & .0072 & 17.0111 & .4236 & 0.402 & 4.621 & 92.534 & 1.3096 & 121123 \\
\hline Loans/Deposits & .0305 & 14.3089 & .7651 & 0.4016 & 6.489 & 35.207 & 1.2009 & 21473.77 \\
\hline Return on Assets & .0020 & .0243 & .0270 & .0065 & 4.016 & 2.290 & .02032 & 205.608 \\
\hline LOG Assets & 2.1739 & 4.5618 & 3.0780 & 3.070 & 7.238 & .006 & .3718 & 08.62 \\
\hline Observations & 320 & 320 & 320 & 320 & 320 & 320 & 320 & 320
\end{tabular}

Table 6. indicates that all variables are asymmetrical especially Skewness. In terms of all variables Skewness is positive except for the capital adequacy ratio. Kurtosis value is not normally distributed. The value of kurtosis are deviated from 3. Jarque-Bera and p-values are used to test the assumption of normality. Accordingly, Jarque-Bera and $\mathrm{p}$-value is rejected at $1 \%$ level of significance.

Table 7. correlations of coefficient matrix

\begin{tabular}{|c|c|c|c|c|c|c|c|}
\hline & CAR & $\begin{array}{l}\text { Loans / } \\
\text { Asst. }\end{array}$ & $\begin{array}{l}\text { Bank. } \\
\text { Efficie. }\end{array}$ & $\begin{array}{l}\text { Prov / } \\
\text { loans }\end{array}$ & $\begin{array}{l}\text { Loans / } \\
\text { Depos. }\end{array}$ & ROA & $\begin{array}{l}\text { Log. } \\
\text { Assets }\end{array}$ \\
\hline Capital adequacy ratio & 1 & & & & & & \\
\hline Loans / Assets & $0.319^{* *}$ & 1 & & & & & \\
\hline $\begin{array}{l}\text { Bank. overall } \\
\text { efficiency }\end{array}$ & $0.483^{* *}$ & $0.624^{* *}$ & 1 & & & & \\
\hline Provisions / Loans & $0.460^{* *}$ & $0.419^{* *}$ & $-0.532^{*}$ & 1 & & & \\
\hline Loans / Deposits & -0.108 & $0.199^{* *}$ & 0.403 & $0.398^{* * *}$ & 1 & & \\
\hline Return on assets & $0.210^{* *}$ & $0.441^{* *}$ & $0.583^{*}$ & $-0.601^{* *}$ & $0.551^{* *}$ & 1 & \\
\hline Log. Assets. & $0.390^{* *}$ & $0.277^{*}$ & $-0.686^{*}$ & $0.112^{* *}$ & -0.255 & $0.579^{* *}$ & 1 \\
\hline
\end{tabular}

**. Correlation is significant at the 0.01 level (2-tailed).

*. Correlation is significant at the 0.05 level (2-tailed).

Table 7. indicate that all independent variables have a significant positive relationship with the efficiency of banks except the liquidity. Liquidity has a negative and non-significant relationship with the efficiency of banks. we can conclude that during the study period from year 2002 to 2015 the Efficiency of Banks has a positive relationship with capital adequacy ratio, credit risk, profitability, size and the quality of management. We accept the alternative hypothesis stating that the relationship between efficiency of banks and capital adequacy ratios is positive. To further investigate the nature of the relationship between the capital adequacy ratios and the efficiency of banks. A panel regression analysis was conducted on the study variables pre and post the financial crisis. Banks are divided into three main groups;. 30 Conventional commercial banks, 5 conventional commercial banks with Islamic windows, 5 Islamic banks pre and post the global financial crisis. We used Eviews software to run the analysis.

Applied to conventional banks, table 8. Show that in view of the period pre the financial crisis, there is a significant positive relationship between the efficiency of banks and capital adequacy ratio, profitability, size, credit risk and the quality of management, whereas a significant negative relationship with liquidity. Results are rational since total 
loan and income variable were used as an approach to measure the output, total deposits and assets of the Bank as an approach to measure the input when calculating the total efficiency of Egyptian banks. Capital adequacy ratio reflect the relative importance of the Bank's capital to risk assets. Efficient banks are exposed to higher credit risk, higher capital adequacy ratio, higher provisions of loans. Thus, the relationship between the efficiency of banks and capital adequacy ratios is positive. These results establish the idea that the central bank of Egypt can allow efficient banks to accept more risk in order to achieve higher return. The high risk accepted by efficient banks are reflected in higher credit risk and higher capital adequacy ratio. The explanatory power of the model is $68.1 \%$.

post the financial crisis, the efficiency of conventional banks decreased, besides there is a distortion in the relationship between the efficiency of banks and other variables. The inefficiency of conventional banks post the financial crisis leads to the increase in capital and taking less risk. As a result, there is a significant negative relationship between the efficiency of banks and capital adequacy ratios and liquidity. However, there is a positive relationship between the inefficiency of banks and credit risk, the quality of management, profitability and size. The efficiency of conventional banks affected by the financial crisis, especially with the existence of securities portfolios invested in the international markets as well as the presence of several branches outside Egypt. In that case conventional banks increased capital adequacy ratio in order to meet Basel requirements and reduce risk exposure. The explanatory power of the model is $32.2 \%$.

Table 8. multiple regression analysis of conventional banks pre and post the financial crisis

\begin{tabular}{lcccccc}
\hline \multirow{2}{*}{ study variables } & \multicolumn{3}{c}{ year $2002-2008$} & \multicolumn{3}{c}{ year 2009-2015 } \\
\cline { 2 - 7 } & $\beta$ & $\mathrm{t}$ & sig. & $\beta$ & $\mathrm{t}$ & sig. \\
\hline Constant & 0.456 & 5.763 & $0.00^{* *}$ & 0.617 & 4.263 & 0.000 \\
\hline Capital adequacy & 0.304 & 2.283 & $0.040^{* *}$ & -0.201 & 8.813 & 0.024 \\
\hline Net loans / total assets & 0.301 & 4.412 & 0.146 & 0.213 & 1.590 & 0.514 \\
\hline Provisions/ total loans & 0.429 & -3.890 & $0.003^{* *}$ & 0.041 & 0.516 & 0.458 \\
\hline Loans / deposits & -0.141 & 1.585 & 0.115 & -0.233 & 2.361 & 0.419 \\
\hline Return on assets & 0.731 & 2.807 & $.000^{* * *}$ & 0.060 & 0.649 & 0.429 \\
\hline Log assets & 0.410 & 4.109 & $.000^{* * *}$ & 0.339 & 7.428 & $0.000^{* *}$ \\
\hline Adjusted R ${ }^{2}$ & \multicolumn{7}{c}{0.681} & & & 0.322 & \\
\hline F-equation & 13.528 & & 7.890 & \\
\hline Prob. (F-statistics) & 0.000 & & & \\
\hline
\end{tabular}

Note: $* * *, * * *$ Significant at 10,5 and $1 \%$ respectively.

Applied to conventional banks with Islamic windows, for the period pre the financial crisis, results concluded that a low explanatory power to the model at rate $57.1 \%$ compared to $68.1 \%$ for conventional banks during the same period. Table 9. Shows that the efficiency of banks still have a positive and significant relationship with capital adequacy ratios, credit risk, size, profitability and the quality of management. however a not significant negative relationship with liquidity. After the financial crisis, the explanatory power of the model increased to $44 \%$ compared to $32 \%$ for conventional banks. There is a positive significant relationship between the efficiency of banks and capital adequacy ratios and credit risk. But other variables shows a non- significant relationship with the efficiency of Egyptian commercial banks with Islamic windows. This indirectly refers to that the efficiency of commercial banks with Islamic windows has slightly improved after the global financial crisis compared to the efficiency of conventional Egyptian banks over the same period. 
Table 9. multiple regression analysis of conventional banks with IW's ${ }^{*}$ pre \& post the financial crisis

\begin{tabular}{lcccccc}
\hline \multirow{2}{*}{ Study variables } & \multicolumn{3}{c}{ year 2002 to 2008} & \multicolumn{2}{c}{ year 2009 to 2015 } \\
\cline { 2 - 7 } & $\beta$ & $\mathrm{t}$ & sig. & $\beta$ & $\mathrm{t}$ & sig. \\
\hline Constant & 0.410 & 6.215 & $0.00^{* *}$ & 0.210 & 3.064 & 0.000 \\
\hline Capital Adequacy & 0.404 & 3.917 & $0.030^{* *}$ & 0.422 & 9.210 & 0.042 \\
\hline Net Loans / Total Assets & 0.219 & 2.144 & 0.641 & 0.321 & 4.692 & 0.754 \\
\hline Provisions/ Total Loans & -0.518 & -2.470 & $.004^{* *}$ & -0.030 & 0.361 & 0.045 \\
\hline Loans / Deposits & 0.243 & 3.258 & 0.235 & 0.323 & 1.243 & 0.508 \\
\hline Return on Assets & 0.431 & 5.603 & $.000^{* * *}$ & 0.061 & 0.745 & 0.520 \\
\hline Log Assets & 0.322 & 3.109 & $.002^{* *}$ & -0.258 & 6.382 & $0.01^{* *}$ \\
\hline Adjusted R & & 0.571 & & & 0.442 & \\
\hline F-equation & & 12.607 & & & 8.872 & \\
\hline Prob. (F-statistics) & & 0.000 & & & 0.000 & \\
\hline
\end{tabular}

Note: $*, * *, \quad * * *$ Significant at 10,5 and $1 \%$ respectively.

In terms of Islamic banks before the financial crisis, the model explanatory power is $37 \%$. Table 10 . shows that the efficiency of Egyptian Islamic banks has a negative and significant relationship with capital adequacy ratios, credit risk, liquidity and size. Whilst, a positive but no significant relationship with profitability and the quality of management. These results are rational since the market share of Islamic banks are small compared to conventional banks which was reflected in the operational performance of Islamic banks. After the financial crisis, results improved with an explanatory power 57\% compared to $32.2 \%$ for conventional banks and $44 \%$ compared to conventional banks with Islamic windows. The efficiency of Islamic banks shows a positive significant relationship with capital adequacy, credit risk, Size, profitability and the quality of management. whilst, a negative significant relationship with liquidity.

Table 10. multiple regression analysis of Islamic banks pre and post the financial crisis

\begin{tabular}{lcccccc}
\hline \multirow{2}{*}{ study variables } & \multicolumn{3}{c}{ Year 2003 to 2008} & \multicolumn{3}{c}{ Year 2009 to 2014 } \\
\cline { 2 - 7 } & $\beta$ & $\mathrm{t}$ & sig. & $\beta$ & $\mathrm{t}$ & sig. \\
\hline Constant & 0.230 & 4.215 & $0.01^{* *}$ & 0.302 & 3.004 & 0.000 \\
\hline Capital Adequacy & -0.204 & 2.197 & $0.040^{* *}$ & 0.521 & 8.021 & $0.034^{* *}$ \\
\hline Net Loans / Total Assets & 0.119 & 3.144 & 0.050 & 0.423 & 5.296 & $0.045^{* *}$ \\
\hline Provisions/ Total Loans & -0.109 & -3.740 & $.003^{* *}$ & 0.340 & 0.136 & $0.040^{* *}$ \\
\hline Loans / Deposits & -0.242 & 2.852 & $0.012^{*}$ & -0.421 & 2.220 & 0.805 \\
\hline Return on Assets & 0.280 & 3.207 & $0.00^{* *}$ & 0.652 & 0.547 & $0.050^{* *}$ \\
\hline Log Assets & -0.233 & 4.308 & $0.004^{* *}$ & 0.752 & 6.483 & $0.04^{* *}$ \\
\hline Adjusted R & & 0.371 & & & 0.570 & \\
\hline F-equation & & 6.507 & & & 12.278 & \\
\hline Prob. (F-statistics) & & 0.000 & & & 0.000 & \\
\hline
\end{tabular}

Note: * **, *** Significant at 10,5 and $1 \%$ respectively.

It is surprising to see the performance of Islamic banks outperformed other banks categories since the explanatory power of the model is increased to reach $57 \%$.

We refuse the second hypothesis since there is a statistical significant difference between the three main categories of banks; Islamic banks, conventional and conventional banks with Islamic windows when investigating the relationship between bank's efficiency and capital adequacy ratios: pre and post the global financial crisis. 


\section{Conclusions}

The efficiency of banks and the capital adequacy ratios were not sufficiently studied on banks operate in Egypt. This is the first study to examine the efficiency of banks operate in Egypt, depending on banks categories; conventional banks, conventional banks with Islamic windows and Islamic banks. Furthermore, to investigate the relationship between the efficiency of banks and capital adequacy ratios. The study period is the main driver to investigate this relationship due to the interest of regulators in Egypt to maintain the capital adequacy ratios proposed by Basel Committee as a precaution after the financial crisis in 2007 and 2008.

We estimated the efficiency of 30 conventional banks, 5 conventional banks with Islamic windows and 5 Islamic banks by applying DEA. Our analysis shows that Islamic banks are less efficient than conventional banks and conventional banks with Islamic windows before the global financial analysis, the efficiency of conventional banks outperformed other banks categories. After the global financial crisis, the efficiency of Islamic banks outperformed other banks categories.

The higher the efficiency of Egyptian banks the higher the exposure of banks to risk due to the presence of risky assets. As supported by Mosko, Aida, Bozdo, Ailda (2015). The more the regulatory bodies in Egypt to require banks to strengthen the capital base to comply with capital adequacy ratios in accordance with the conditions of Basel Committee. The lower the efficiency of banks the lower the exposure of banks to risk due to the decrease of risky assets. Inefficient banks allocate more resources to monitor and manage international financial portfolios regularly, leading to increased operational costs. Thereby reducing the resources allocated to the loan portfolio and reducing the income generated. Bank's risk is determined by the efficiency of banks and capital as supported by Berger, De Young, Kwan and Eisenbeis (1997).

Pre the financial crisis the efficiency of conventional banks shows a positive and significant relationship with capital adequacy ratios, credit risk, profitability, the quality of management and the bank size. The increase in risky assets is associated with the increase of efficiency for conventional banks. Once bank efficiency is increased, capital adequacy ratios increase, risk appetite of conventional banks increases and profitability rates increase due to the quality of management. Taking into account that the size of the bank is a key factor to increase the market share and attracting more customers. This leads to an increase in loan portfolios. Thus, there is an inverse relationship between the efficiency of the banks and liquidity. The explanatory power of the model is $68 \%$ compared to $57 \%$ for conventional banks with Islamic windows and $37 \%$ for Islamic banks.. Banks with capital appreciation have an additional protection against any adverse fluctuations arising from increased risk tolerance. This relationship negates what is known as a Moral Hazard. These results supported by Altunbas et. Al (2007), Firodelisi et. Al (2010), Mosko. Aida; Bozdo and Arilda (2015) and Miah \& Sharmeen (2015).

In terms of conventional banks with Islamic windows, results concluded that there is a positive significant relationship between banks efficiency and capital adequacy ratios, credit risk, the quality of management, profitability and the size of the bank. There is a negative non- significant relationship with the liquidity. The explanatory power of the model decreased to reach 57\%. The higher the capital base within conventional banks, the higher the risk and the higher capital adequacy ratio.

In terms of Islamic banks, results concluded that there is a significant negative relationship between banks efficiency and capital adequacy ratio, credit risk, liquidity and the size of the bank. Whilst, the efficiency of banks has a positive significant relationship with the quality of management and profitability. The explanatory power of the model is 37\%. The market share of Islamic banks in Egypt is still small, accordingly this has a negative impact on the operations of Islamic banks, decreasing the portfolio of loans and ended up to the decrease in the bank efficiency. Islamic banks do not require maintaining a high cash reserves as in conventional banks. The type of financing at Islamic banks is different from that of conventional banks, and therefore less risky.

After the financial crisis, the efficiency of conventional banks shows a negative significant relationship with capital adequacy ratios whilst a non-significant relationship with the quality of management, liquidity and return on assets. The efficiency of banks shows a positive significant relationship with the bank scale and non-significant with credit risk. The explanatory power of the model is $32 \%$.

In terms of conventional banks with Islamic windows, Banks efficiency shows a significant negative relationship with capital adequacy ratios, credit risk and the banks scale. Other variables; the quality of management, liquidity, and return on assets showed a positive non-significant relationship with the efficiency. The explanatory power of the model is $44 \%$ compared to $32 \%$ for conventional banks and compared to $57 \%$ during the period before the financial crisis. This indirectly refers to that the efficiency of commercial banks with Islamic windows has slightly improved 
after the financial crisis compared to the efficiency of conventional banks over the same period. This shows that the conventional banks' tendency to offer a variety of Islamic products has attracted a new segment of customers, which affected by the efficiency of management through providing credit and therefore increasing the credit risk and the increase in capital adequacy ratios.

In terms of Islamic banks, the efficiency of Islamic banks shows a positive significant relationship with capital adequacy ratios, credit risk, profitability, size and the quality of management. Whilst has a negative significant relationship with liquidity.. Islamic banks outperformed other banks categories since the explanatory power of the model increased to $57 \%$ from $37 \%$ before the financial crisis and compared to $40 \%$ for conventional banks with Islamic windows and 32\% for conventional banks. These results supported by Iqbal (2001), Brown et. Al (2007), Serder et al (2011), and Moktar et al, (2006) study which proved that Islamic banks superior to conventional banks in Malaysia.

Results indicate important applications for financial policy makers in Egypt. Because of the cultural and religious background in Egypt, there is a segment of clients who prefer to deal with Islamic banks, which has attracted a different segment of customers to deal with banks and achieve financial inclusion steps. Islamic banks are more cautious in extending credit, while at the same time they do not require high levels of liquidity because financing patterns of Islamic banks are less risky than conventional banks. Islamic banks are therefore exposed to lower risks than conventional banks. This explains the high efficiency of conventional banks with Islamic windows compared to conventional banks and the high efficiency of Islamic banks compared to conventional banks with Islamic windows. There is still room for Islamic banks to improve their performance and efficiency. Islamic banks were not affected by the global financial crisis. It is clear to notice that the level of bank's efficiency determines the level of risk and capital as supported by Hughes and Mester (1998).

\section{Future Research}

We need to enrich the previous studies in Egypt by comparing the efficiency of local banks and the efficiency of foreign banks. As well as the efficiency of Egyptian banks on capital adequacy ratios applied to local banks and foreign banks in Egypt. We need to conduct the study at different intervals to reach to the nature of the relationship.

\section{Practical Implications}

The increase in further adoption of the Islamic finance system in Egypt support the development of the economy. There is still a room for the development of Islamic banks and the spread of Islamic financing modes and support financial inclusion and integration of the economy.

Acknowledgements: to my parents, to my wife Eng. Asmaa Sharawy, to my kids; Hana my little princess, Omar my naughty son and Ali king of math.

\section{References}

Abduh, M., \& Chowdhury, N. T. (2012). Does Islamic banking matter for economic growth in Bangladesh. Journal of Islamic Economics, Banking and Finance, 8(3), 104-113.

Abduh, M., Hasan, S. M., \& Pananjung, A. G. (2013). Efficiency and performance of Islamic Banks in Bangladesh. Journal of Islamic Banking and Finance, 30(2), 94-106.

Ahmed, AUF \& Hassan, M.K. (2007b). Regulation and performance of Islamic banking in Bangladesh. Thunderbird International Business Review, 49(2), 251-277. https://doi.org/10.1002/tie.20142

Ahmed, AUF \& Hassan, M.K. (2007a), Riba and Islamic Banking. Journal of Islamic Economics, Banking and Finance, 3(1), 9-42.

Aigner, D., Lovell, C. K., \& Schmidt, P. (1977). Formulation and estimation of stochastic frontier production function models. Journal of econometrics, 6(1), 21-37. https://doi.org/10.1016/0304-4076(77)90052-5

Akther, S., Fukuyama, H., \& Weber, W. L. (2013). Estimating two-stage network slacks-based inefficiency: An application to Bangladesh banking. Omega, 41(1), 88-96. https://doi.org/10.1016/j.omega.2011.02.009

Al Rajhi, A. S. (1999). Islamic Banks: Technology and Global Challenges and Opportunities. In Proceedings Third Harvard University Forum on Islamic Finance, October 1.

Alam, M. (1995). Islamic banking in Bangladesh: a case study of IBBL. International Journal of Islamic Financial Services, 1(4), 10-29.

Alam, N. (2013). Impact of banking regulation on risk and efficiency in Islamic banking. Journal of Financial 
Reporting and Accounting, 11(1), 29-50. https://doi.org/10.1108/JFRA-03-2013-0010

Al Janabi, M. A. (2008). Proactive risk management in emerging and Islamic financial markets: Evidence from the Moroccan financial markets. Humanomics, 24(2), 74-94. https://doi.org/10.1108/08288660810876804

Altunbas, Y., Carbo, S., Gardener, E. P., \& Molyneux, P. (2007). Examining the relationships between capital, risk and efficiency in European banking. European Financial Management, 13(1), 49-70. https://doi.org/10.1111/j.1468-036X.2006.00285.x

Bader, M. K. I., Mohamad, S., Ariff, M., \& Hassan, T. (2008). Cost, revenue and profit efficiency of Islamic versus conventional banks: International evidence using data envelopment analysis. Islamic Economic Studies, 15(2), 23-76.

Beck, T., Demirgüç-Kunt, A., \& Merrouche, O. (2013). Islamic vs. conventional banking: Business model, efficiency and stability. Journal of Banking \& Finance, 37(2), 433-447. https://doi.org/10.1016/j.jbankfin.2012.09.016

Berger, A. N. (1995). The profit-structure relationship in banking--tests of market-power and efficient-structure hypotheses. Journal of Money, Credit and Banking, 27(2), 404-431. https://doi.org/10.2307/2077876

Berger, A. N., \& DeYoung, R. (1997). Problem loans and cost efficiency in commercial banks. Journal of Banking \& Finance, 21(6), 849-870. https://doi.org/10.1016/S0378-4266(97)00003-4

Berger, A. N., \& Humphrey, D. B. (1992). Measurement and efficiency issues in commercial banking. In Output measurement in the service sectors (pp. 245-300). University of Chicago Press.

Berger, A. N., \& Humphrey, D. B. (1997). Efficiency of financial institutions: International survey and directions for future research. European journal of operational research, 98(2), 175-212. https://doi.org/10.1016/S0377-2217(96)00342-6

Berger, A. N., Hunter, W. C., \& Timme, S. G. (1993). The efficiency of financial institutions: A review and preview of research past, present and future. Journal of Banking \& Finance, 17(2-3), 221-249. https://doi.org/10.1016/0378-4266(93)90030-H

Bourkhis, K., \& Nabi, M. S. (2013). Islamic and conventional banks' soundness during the 2007-2008 financial crisis. Review of Financial Economics, 22(2), 68-77. https://doi.org/10.1016/j.rfe.2013.01.001

Brown, K., Hassan, M. K., \& Skully, M. (2007). Operational efficiency and performance of Islamic banks. Handbook of Islamic banking, 96. https://doi.org/10.4337/9781847205414.00016

Charnes, A., Cooper, W. W., \& Rhodes, E. (1979). Measuring the efficiency of decision-making units. European journal of operational research, 3(4), 339. https://doi.org/10.1016/0377-2217(79)90229-7

Colwell, R., \& Davis, E. (1992). Output and productivity in banking. Scandinavian Journal of Economics, 94(1), 111-129. https://doi.org/10.2307/3440252

Caves, D. W., Christensen, L. R., \& Diewert, W. E. (1982). The economic theory of index numbers and the measurement of input, output, and productivity. Econometrica: Journal of the Econometric Society, 1393-1414. https://doi.org/10.2307/1913388

Cooper, W. W., Seiford, L. M., \& Zhu, J. (2004). Data envelopment analysis. In Handbook on data envelopment analysis (pp. 1-39). Springer, Boston, MA. https://doi.org/10.1007/1-4020-7798-X_1

Deelchand, T., \& Padgett, C. (2009). The relationship between risk, capital and efficiency: Evidence from Japanese cooperative banks.

Fiordelisi, F., Marques-Ibanez, D., \& Molyneux, P. (2011). Efficiency and risk in European banking. Journal of Banking \& Finance, 35(5), 1315-1326. https://doi.org/10.1016/j.jbankfin.2010.10.005

Floquet, K., \& Biekpe, N. (2008). The relationship between capital structure and risk in emerging market banks. Problems and Perspective in Management, 6(4), 24-36.

Fries, S., \& Taci, A. (2005). Cost efficiency of banks in transition: Evidence from 289 banks in 15 post-communist countries. Journal of Banking \& Finance, 29(1), 55-81. https://doi.org/10.1016/j.jbankfin.2004.06.016

Hasan, M., \& Dridi, J. (2011). The effects of the global crisis on Islamic and conventional banks: A comparative study. Journal of International Commerce, Economics and Policy, 2(02), 163-200. https://doi.org/10.1142/S1793993311000270

El-Ansary, O., \& Hafez, H. M. (2015). Determinants of Capital Adequacy Ratio: An Empirical Study on Egyptian 
Banks.

Hassan, M. K. (2006). The X-efficiency in Islamic banks. Islamic economic studies, 13(2), 49-78.

Karim, M. Z. A., Chan, S. G., \& Hassan, S. (2010). Bank efficiency and non-performing loans: Evidence from Malaysia and Singapore. Prague Economic Papers, 2(2010), 118-132. https://doi.org/10.18267/j.pep.367

Kwan, S., \& Eisenbeis, R. A. (1997). Bank risk, capitalization, and operating efficiency. Journal of financial services research, 12(2-3), 117-131. https://doi.org/10.1023/A:1007970618648

Kumbhakar, S. C., \& Lovell, C. K. (2003). Stochastic frontier analysis. Cambridge university press.

Abdul-Majid, M., Saal, D. S., \& Battisti, G. (2008). Efficiency in Islamic and conventional banking: An international comparison. Aston University.

Miah, M. D., \& Sharmeen, K. (2015). Relationship between capital, risk and efficiency: A comparative study between Islamic and conventional banks of Bangladesh. International Journal of Islamic and Middle Eastern Finance and Management, 8(2), 203-221. https://doi.org/10.1108/IMEFM-03-2014-0027

Mokhtar, H. S. A., Abdullah, N., \& Al-Habshi, S. M. (2006). Efficiency of Islamic banking in Malaysia: A stochastic frontier approach. Journal of Economic Cooperation, 27(2), 37-70.

Mosko, A., \& Bozdo, A. (2016). Modeling the relationship between bank efficiency, capital and risk in Albanian banking system. Procedia Economics and Finance, 39, 319-327. https://doi.org/10.1016/S2212-5671(16)30330-6

Roy, D. A. (1991). Islamic banking. Middle Eastern Studies, 27(3), $427-456$. https://doi.org/10.1080/00263209108700869

Sardar, A., Azeem, M. M., Ahmed, T., \& Zafar, S. (2011). Islamic Banks: Efficiency and its Determinants in Pakistan. Islamic Studies, 423-434.

Sarkis, J. (2007). Preparing your data for DEA. In Modeling data irregularities and structural complexities in data envelopment analysis (pp. 305-320). Springer, Boston, MA. https://doi.org/10.1007/978-0-387-71607-7_17

Shrieves, R. E., \& Dahl, D. (1992). The relationship between risk and capital in commercial banks. Journal of Banking \& Finance, 16(2), 439-457. https://doi.org/10.1016/0378-4266(92)90024-T

Tan, Y., \& Floros, C. (2013). Risk, capital and efficiency in Chinese banking. Journal of International Financial Markets, Institutions and Money, 26, 378-393. https://doi.org/10.1016/j.intfin.2013.07.009

Thanassoulis, E. (2001). Introduction to the theory and application of data envelopment analysis. Dordrecht: Kluwer Academic Publishers. https://doi.org/10.1007/978-1-4615-1407-7

Zellner, A. (1962). An efficient method of estimating seemingly unrelated regressions and tests for aggregation bias. Journal of the American statistical Association, $\quad$ 57(298), $348-368$. https://doi.org/10.1080/01621459.1962.10480664 